\title{
Ochre roasting: the enigma of an unusual lime kiln alteration at the Cheddleton Flint Mills, near Leek, north Staffordshire.
}

\author{
By ALAN OUTRAM
}

The Cheddleton Mills are located on a diverted section of the river Churnet in the village of Cheddleton, near Leek, in the Staffordshire Moorlands (Grid. Ref. SJ972526) (see Fig. 1). The earliest reference to milling at Cheddleton dates to $1253,{ }^{1}$ and it is clear that the lower part of the South Mill is of medieval construction. A reference of 1694 refers to the milling of corn. In the 1780s, however, the North Mill was constructed for the deliberate purpose of grinding flint and the South Mill was converted to serve the same purpose. ${ }^{2}$ The ground, calcined flint was destined for the Staffordshire pottery industry where it was used as a raw material in the manufacture of earthenwares. Transport of materials in and out of the Cheddleton Mills was via the Caldon Canal which was completed in 1.777 . This canal was originally constructed to extend trade in limestone from the Caldon Low quarries. ${ }^{3}$

The Cheddleton Flint Mills are now an open air museum and its two flint kilns, used for calcining the flint, are on view to the public next to the canal wharf (see Fig. 2). A third potential firemouth, however, had always been visible adjacent to the flint kilns (Fig. 2) and a notice of sale in the Staffordshire Advertiser, dated 1815, lists a lime kiln along with the two flint kilns. ${ }^{4}$ We know, from the living memory of locals and old film footage, that this kiln must have been covered sometime before the 1920 s. It was decided to excavate above the third firemouth to establish if anything of this kiln survived (see Fig. 2).

Below approximately $30 \mathrm{~cm}$. of topsoil and overburden, a semi-circle of bricks, to the canal side of the excavation, were found. These bricks did not, however, continue round to the mill side of the excavation. Instead,

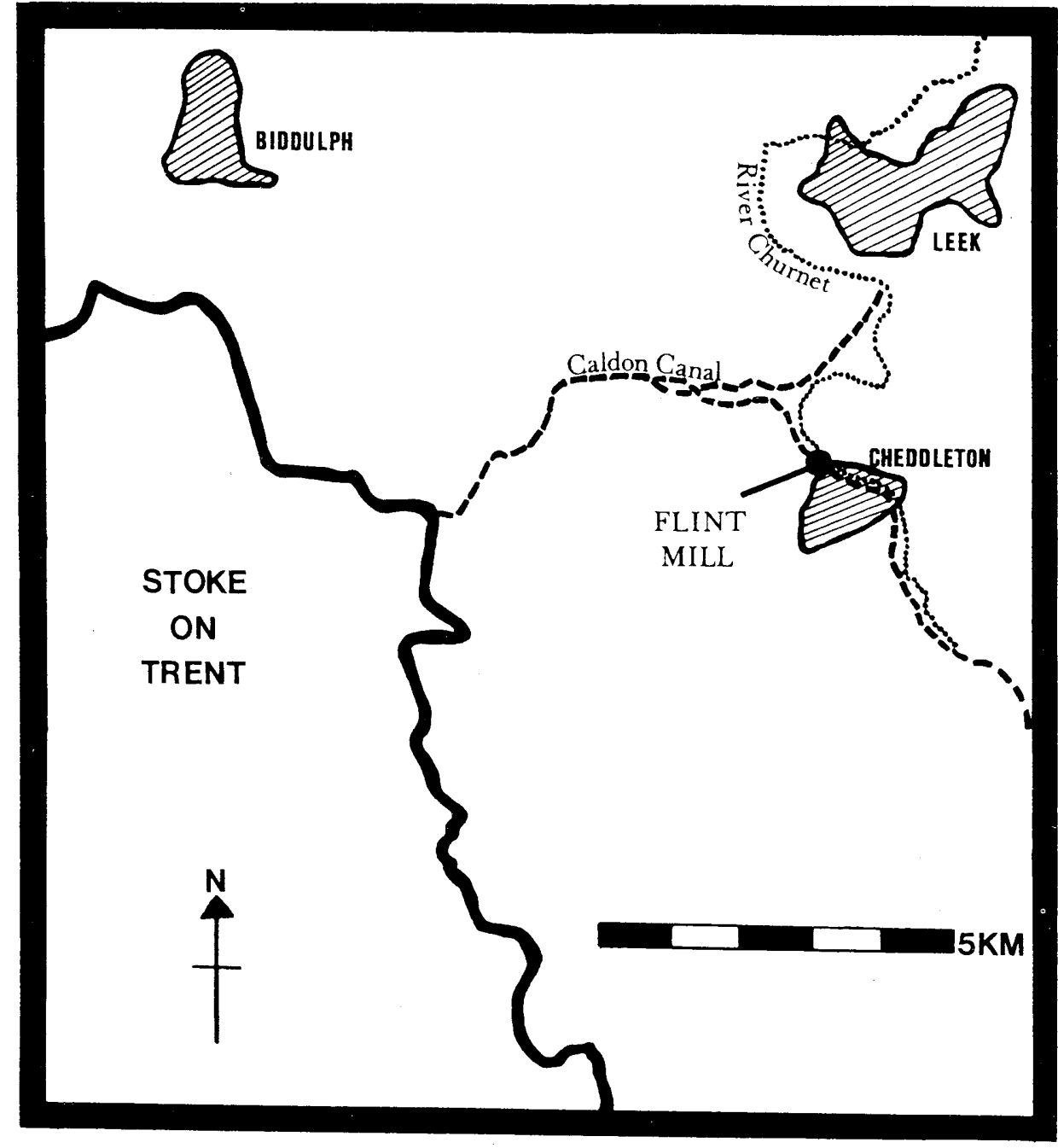

FIG. 1

Map showing the location of the Cheddleton Mills. 


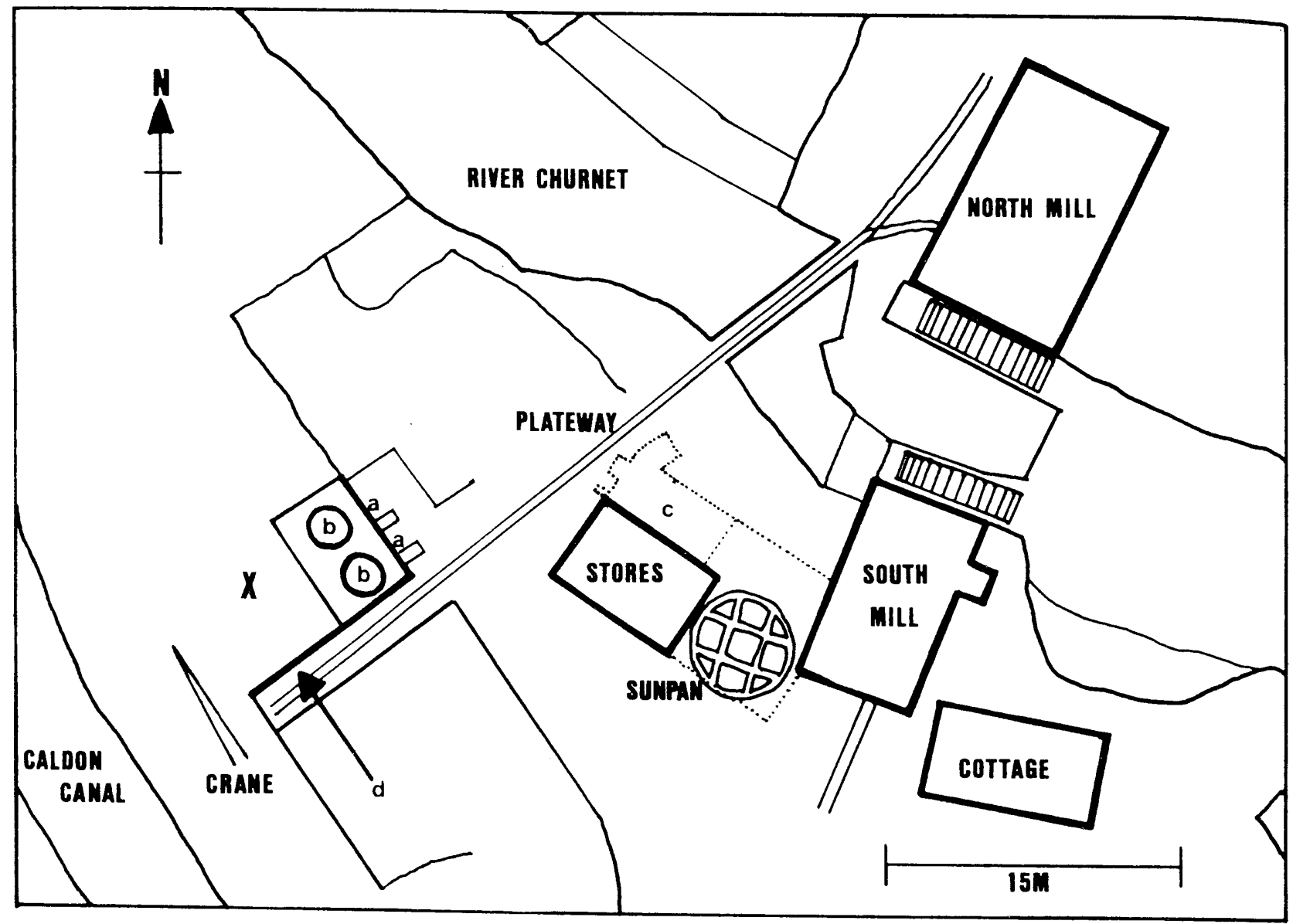

FIG. 2

The Cheddleton Mills circa 1785.

Key: (a) Flint Kiln Firemouths, (b) Flint Kilns, (c) Slip Kiln added c.1830, (d) The Third Firemouth, (X) Site of Excavation.

there was much stone and brick rubble (see Fig. 3). On removal of this it became clear that the upper part of the kiln, which arches inwards, had been demolished on this side. The kiln, however, still appeared to retain deliberately laid, original contents over the whole of its circle.

These contents were half-sectioned, removing the material on the mill side. There were three neat layers of material (see Fig. 4). The upper of these was red shaley material, the middle layer appeared to be a yellow ochre or ironstone and the bottom layer was coal (apparently unfired). Below these layers was a floor constructed of large stone slabs with gaps being filled with on-edge bricks. At this level the continuation of the kiln wall circle, on the mill side, was located. Excavation of the other side of the kiln revealed the continuation of the flooring (Figs 5 \& 6). Lifting one of the stone slabs indicated that the rest of kiln below had been in-filled with mixed rubble.

The fact that the coal layer seemed to spill out over the kiln wall on the lower, mill side suggests that the top, arching part of the kiln wall had been removed before the coal, ochre and red material were placed on the flooring within the kiln. To summarise, it seems that what was probably originally a lime kiln has been infilled, up to the point where its wall starts to curve inwards, and a floor laid. One side of the upper kiln wall has then been removed and three layers of material, apparently deliberately laid upon the floor.

The very deliberate, and what must have been costly and time-consuming, alterations suggest that an attempt was being made to convert the kiln to some other industrial function. It would be logical to assume that what was intended was to roast the ochre/ironstone layer above the coal, with the red layer perhaps forming an insulating covering. A chemical analysis of the brickwork, ochre/ironstone and brickwork surface slag gives us a fuller picture (see Table 1). The brick lining of the kiln is of a different colour to the flint kilns, but the $\mathrm{SiO}_{2}: \mathrm{Al}_{2} \mathrm{O}_{3}$ ratio with low quantities of alkali provides sufficient refractories for a simple shaft kiln and would be stable up to around $1100 / 1200^{\circ} \mathrm{C} .^{5}$ This is consistent with the construction of lime kilns. The 


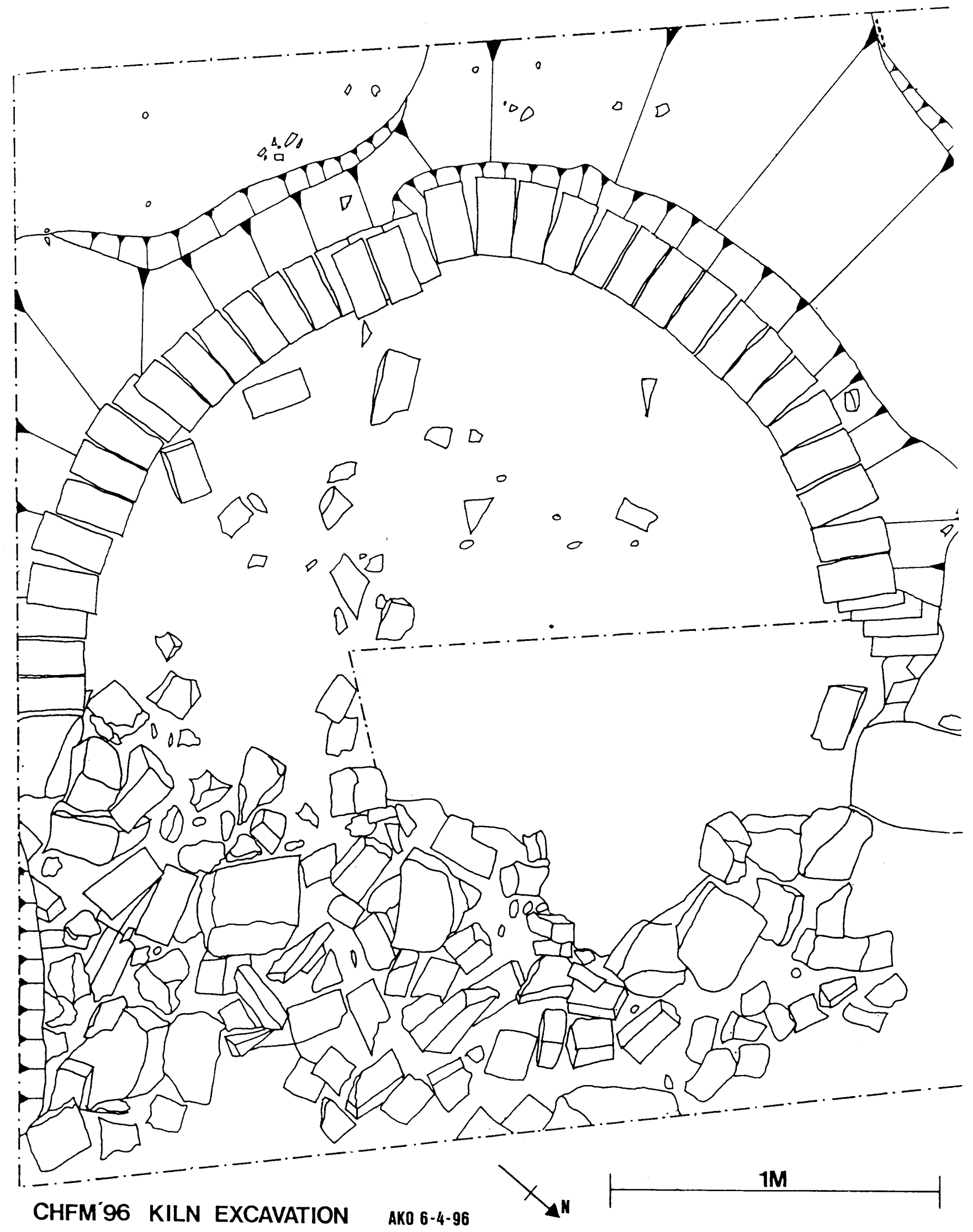

FIG. 3

The kiln excavation after removal of topsoil and overburden. 

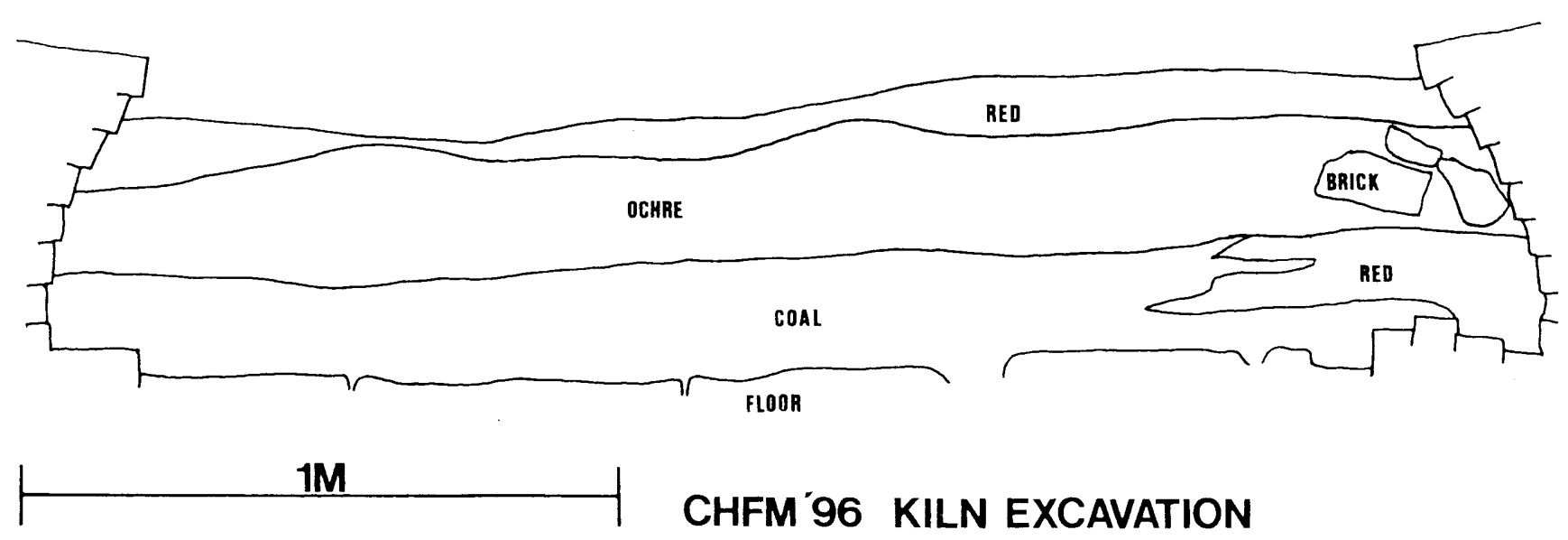

FIG. 4

The N.E. facing section of the kiln contents.

yellow material is certainly an ironstone/ochre, with a $68.76 \% \mathrm{Fe}_{2} \mathrm{O}_{3}$ content, but contains too much impurity to be useful in metallic iron production. The material changes to purple/red colour on firing to $950^{\circ} \mathrm{C}^{6}$ The slag on the brick lining appears to be largely a primitive calcium silicate glass which is consistent with the structure having been a lime kiln. ${ }^{7}$

The roasting of ochre, for use as a colour, is well known. The process of calcining ochre, to produce red colours on a large scale, was first patented in $1794 .^{8} \mathrm{~A} 19$ th-century account tells us that 'the ochrey earths are prepared by grinding and washing; in some cases they are also exposed to the action of fire, to increase the oxidation of the iron and deepen the colour'. ${ }^{9}$ It is possible that the altered kiln was intended for the firing of yellow ochre to produce a red colour for use in decoration in the ceramics industry. This is, however, unlikely since the production of such colours requires very close control of temperature and atmosphere that could not be achieved in a kiln like the one under discussion. ${ }^{10}$

It is very possible, though, that roasted ironstone/ochre might have been intended as a ceramic body ingredient. In an account roughly contemporary with the probable use of this kiln, Simeon Shaw, in his History of the Staffordshire Potteries, lists iron oxide as an important additive to the clays for the production of 'Egyptian Black' wares. ${ }^{11}$ Another 19th-century account gives several recipes for black bodied wares. ${ }^{12}$ The average recipe content is $43 \%$ ball clay, $43 \%$ ground ochre and $13 \%$ manganese. It seems very likely that bulk quantities of roughly fired ochre were most likely intended as constituents for 'Egyptian Black' and 'Black Basalt' wares.

This kiln alteration, however, still remains difficult to understand. There is no obvious evidence that it was ever fired. The coal was in unfired state and the slag on the lining was suggestive of only the kiln's prior use. Furthermore, the kiln seems to have been constructed without obvious updraft or firemouths. It seems hard to see how it was ever functional. A further important point is that this apparent attempt to process a strongly coloured material was occurring right next to the production of calcined flint, a 'white' process. Ceramic material producers and pottery manufacturers always keep white and coloured processes apart, often to the extent of having separate factories. ${ }^{13}$ This kiln alteration, therefore, seems to be both ill-advised and illconstructed, but such a level of incompetence seems hard to believe. Is there another more sensible

Table 1: Results of XRF Analysis of kiln materials giving percentages of constituents.

\begin{tabular}{lccc}
\hline & Brick Lining & Slag on Lining & Ironstone \\
\hline $\mathbf{A l}_{\mathbf{2}} \mathbf{O}_{\mathbf{3}}$ & 24.5 & 17.84 & 5.2 \\
$\mathrm{SiO}_{\mathbf{2}}$ & 58.9 & 33.5 & 20.2 \\
$\mathbf{C a O}$ & 0.83 & 28.9 & 1.1 \\
$\mathbf{A l k a l i}$ & 3 & 3 & 1.7 \\
$\mathbf{F e}_{\mathbf{2}} \mathbf{O}_{\mathbf{3}}$ & 9.89 & 12.5 & 68.76 \\
$\mathbf{P}_{\mathbf{2}} \mathbf{O}_{\mathbf{3}}$ & 0.28 & 0.78 & 2.14 \\
Other & 2.6 & 3.48 & 0.9 \\
\hline
\end{tabular}
explanation? 


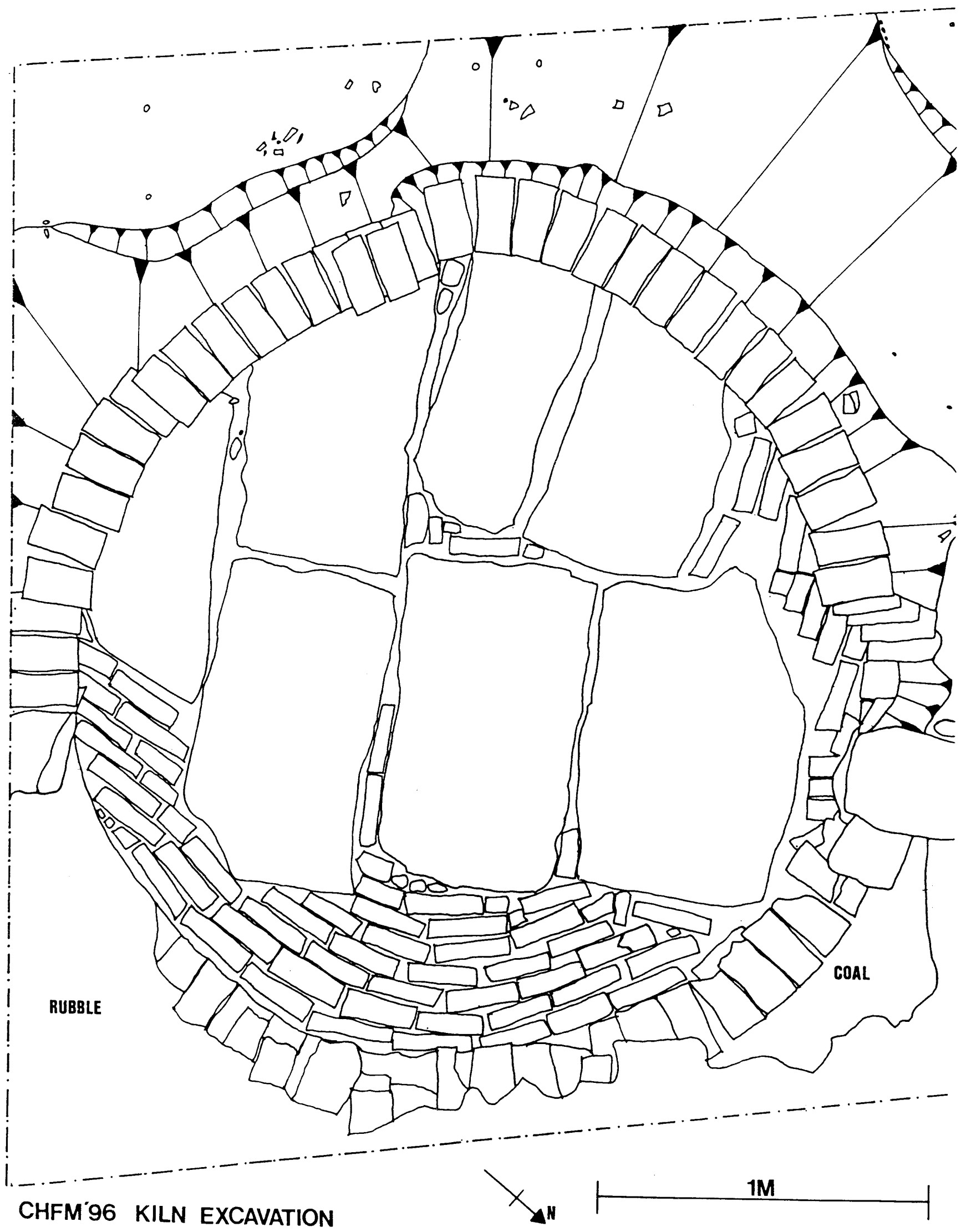

FIG. 5

The kiln and added floor after removal of contents. 


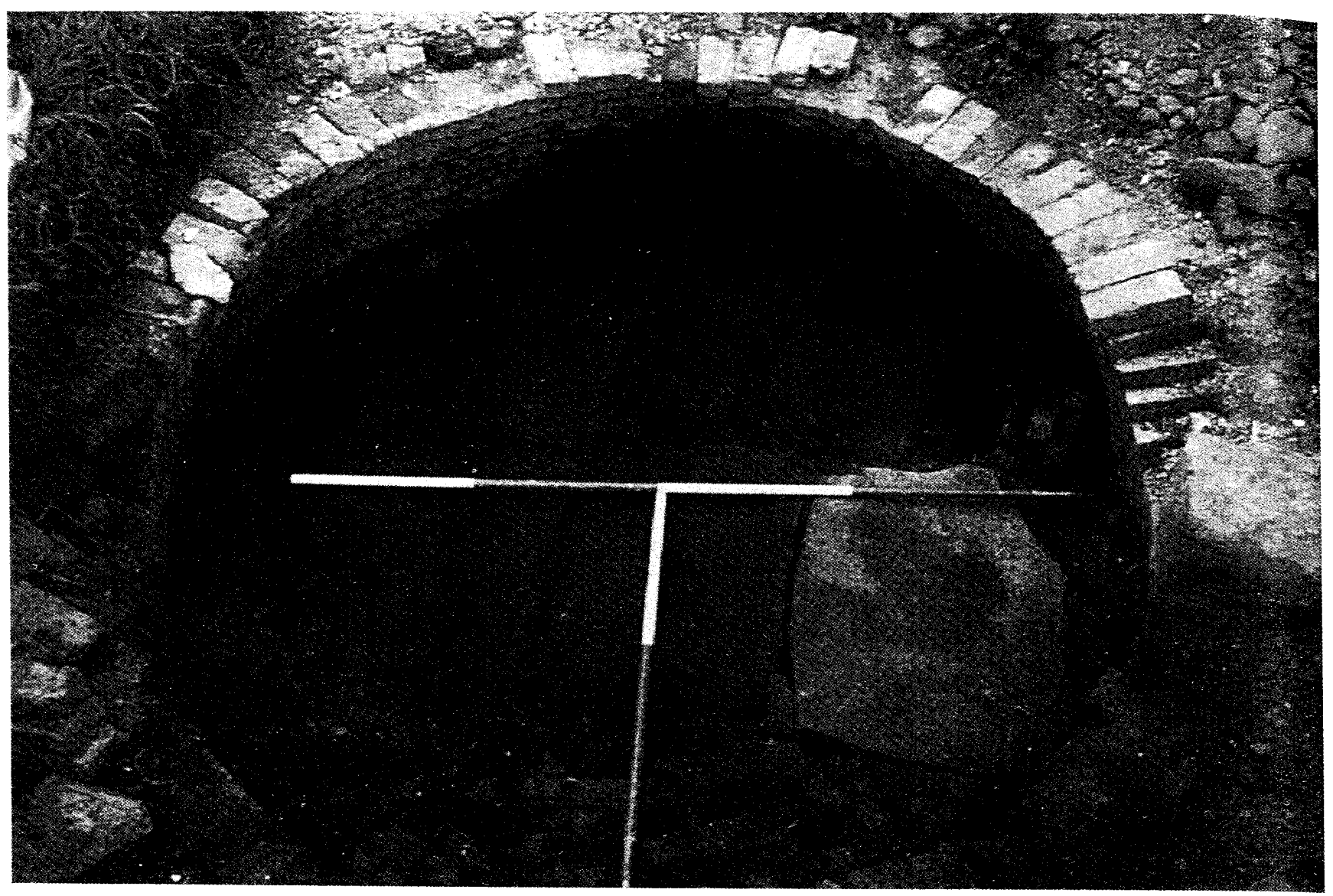

FIG. 6

Photograph of the kiln alteration after removal of contents.

Accounts of the company who owned the mill, dating from around 1890 to 1920 , show that much ochre, ironstone and manganese were traded. The Cheddleton mills at that time were run with two other mills, one at Bucknall the other at Consall, and coloured materials were processed at one or other of these. ${ }^{14}$ Perhaps the intention of the alteration was to make use of a disused lime kiln for the firing of ochre that was to be ground at another mill. The project may have been abandoned before the first firing because of technical problems or the fear of contaminating the white process. On the evidence currently available, one can only speculate and the precise logic behind the alterations remains illusive.

\section{ACKNOWLEDGEMENTS}

The author would like to express thanks to the Cheddleton Flint Mill Industrial Heritage Trust, the Stokeon-Trent Museum Archaeological Society, Ted Royle, Mr and Mrs R. Fleming, Derek Outram and Helen Outram for their role in the excavation and to David Barker, Robert Copeland, George Edwards and John Boyes for their advice. I would also like to thank Mr George Edwards for his characterization of the kiln materials and Mr R. Evans, Director of Messrs Castle Colours Ltd, for undertaking the XRF analysis. 


\section{NOTES}

1 R. Copeland, A Short History of Pottery Raw Materials and The Cheddleton Flint Mill (Cheddleton Flint Mill Industrial Heritage Trust, 1972), 21.

2 Ibid.

3 Ibid.

4 Ibid., p. 22

5 G. Edwards pers. comm.

6 Ibid.

7 Ibid.

8 H. H. Hurst, Painters' colours, Oils, and Varnishes: A Practical Manual (4th ed.) (London, 1906), 118.

9 R. Hunt (ed.) Ure's Dictionary of Arts, Manufactures, and Mines, 3 (5th ed.) (London, 1860), 271.

${ }^{10} \mathrm{G}$. Edwards pers. comm.

${ }^{11}$ S. Shaw, History of the Staffordshire Potteries (1829), 124.

12 W. R. Creyke, Book of Modern Recipes (2nd ed.) (Hanley, 1887).

${ }^{13}$ G. Edwards and R. Copeland pers. comm.

${ }^{14}$ E. Royle pers. comm. 